\title{
AClR
}

Selected Papers of \#AolR2021:

The 22nd Annual Conference of the

Association of Internet Researchers

Virtual Event / 13-16 Oct 2021

\section{MELODRAMATIC PLATFORMS: THE AFFECTIVE THEATRE OF POLARIZED POLITICAL STORYTELLING ON SOCIAL MEDIA}

\author{
Míchílín Ní Threasaigh \\ Ontario Institute for Studies in Education (OISE), University of Toronto \\ Megan Boler \\ Ontario Institute for Studies in Education (OISE), University of Toronto
}

Contrary to claims that social media platforms are not contributing to political polarization, our study of affect and narratives of race and national belonging in social media discourses of the 2019 Canadian and 2020 U.S. federal elections reveals clearly polarized, collective political storytelling marked by a highly affective moralizing tone and clear binaries of us versus them and good versus evil. To understand the roles of affect and narrative in shaping online civic discourse, we ask:

1. What role do emotions play in catalyzing, organizing and circulating polarized political meta-narratives on social media platforms? and,

2. How might we analyse social media expressions as a form of collective political storytelling?

To answer these questions, we draw upon a subset of our data to use the US Capitol Riots as a case-study in the melodramatic genre of collective political storytelling on social media platforms.

\section{Methodology:}

This case-study is situated within our larger cross-platform, mixed-methods research project which engages grounded theory to explore how emotions are expressed in relation to narratives of racial and national belonging within election-related social media debates. This larger study explores Twitter, Facebook, Reddit, YouTube and Gab discussions about the 2019 Canadian and 2020 U.S. elections. With a collaborative team consisting of the $\mathrm{PI}$ and seven graduate research assistants, we conducted a four-month digital ethnography in the lead up to and aftermath of both federal elections, tracking online debates within far right, conservative, liberal, and left social media communities. We documented these in a collaborative and iterative process including extensive field notes and memos, weekly team meetings, and literature reviews. Following each 4-month digital ethnography, we selected 2-4 threads from each platform for a total of 12 threads. In the context of the data for the U.S. election, the 
threads were selected according to the following criteria: initiated by an influencer, reflecting cross-partisan dialogue, explicit address of race, and more than 300 comments/responses. We focused on analysis and coding of the comments to these original posts in order to understand the affective and cross-partisan dynamics of polarization and conflict. Over the next three-month period, we engaged grounded theory (Charmaz, 2006) to develop coding families suitable for the complex task of coding emotional expression, including: rhetorical and linguistic features, objects of emotion, and beliefs about in-groups and out-groups. We then coded a total of 2500 posts for each election with Atlas.ti, using a combination of discourse, rhetorical, and "narrative emotions analysis" (Kleres, 2011).

\section{Theoretical Framework:}

Our theoretical framework was developed as themes emerged from our grounded theoretical work. As we engaged digital ethnographies and coded thousands of posts, what clearly emerged were persistent melodramatic storytelling features surrounding emotional expressions related to narrative of race and nation. We follow Loseke (2009) in examining key elements of this genre present in the construction of polarized political meta-narratives.

The typical plot of a melodrama is an "intense emotional and ethical drama based on the manichaeistic struggle of good and evil" (Brooks, 1976, p. 279), and the main characters are "the morally faultless victim, the ruthless villain, and the heroic savior (Anker, 2005, as cited in Loseke, 2009, p. 503 ). To further understand the plots of these collectively constructed political meta-narratives, we employ Arlie Hochschild's (2016) concepts of "deep stories" and associated "feeling rules" as theoretically sensitizing concepts. Deep stories underlie all political ideologies, and are metaphorical representations of a group's experience, "feels-as-if accounts" that are "stripped of judgment and of facts". These deep stories contain the protagonist's pain, someone or something to blame for this pain, and point to a mechanism for rescue from this pain. They also prescribe an "emotional accounting system" -- what Hochschild calls "feeling rules" -- that govern what the group should and should not feel about events as they unfold in these stories.

In the context of our grounded theory and ethnography, the political meta-narrative that surfaced as a critical finding of our research was in essence a digital version of Hochschild's notion of deep stories -- but significantly, not inclusive of the "rescue" dimensions. The lack of a "rescue narrative" in these stories is indicative of lack of solution-focused discourse on social media platforms. The "overwrought emotion and heightened states of emotional urgency, tension, and tribulation" (Singer cited in Loseke, 2009, p. 503) that characterise the melodramatic genre ensure audiences "unambiguously distinguish between good and evil" (Anker, cited in Loseke, 2009, p. 503).

The language employed by melodrama is a "vocabulary of clear, simple, moral and psychological absolutes' and 'rhetorical excess"' (Brooks cited in Loseke, 2009, p. 503). To understand the emotional work that style is doing in these stories, we engage the 
methodology of "narrative emotion analysis" (Kleres, 2011) to analyze the emotional expression embedded in these meta-narratives -- including emotions not explicitly stated by social media users -- by coding for their linguistic and rhetorical markers.

\section{Findings:}

Our findings reveal social media platforms as melodramatic theatres of emotionally-charged collective political storytelling. The melodramatic genre, as Donileen Loseke (2009) has noted, might be effective in "encouraging audience emotional engagement" (p. 517) due to its oft-disparaged sensational, predictable plots detailing the "triumph of moral virtue over villainy" (Frye, 1957, p.44) in ways that discourage reflection (Wagner-Pacifici, 1986), refuse nuance (Brooks, 1976, p. 36), and ultimately idealize the "moral views assumed to be held by the audience" (Frye, 1957, p.44). Conflicting political meta-narratives constructed around the same event tell near opposite stories of pain and blame, with victims and villains who exchange roles with the discourse community doing the storytelling, with variations of the same characters, Us and Them, with the narrator/self always cast as the protagonist/Victim dueling against their political Other as antagonist/Villain. In contrast to prevailing understandings of polarization as solely shaped by partisan political identity, these discourse communities are formed according to both social and political identities. The meta-narratives constructed by these communities contain a highly affective moralizing tone and clear binaries of us versus them and good versus evil. Negative, compound-emotions of anger/indignance, judgement, dismissal, distrust and disgust are aimed at Them; while love, hope and pride bind Us in networked communities. Coding for rhetorical and linguistic expression of emotions further reveals users employing the melodramatic style of rhetorical excess (evidenced by high incidences of name calling/belittling/mocking, dismissing, conflict/threat language, sarcasm/satire/irony, and emotion language) and a vocabulary of clear, simple, moral and psychological absolutes (evidenced by high incidences of moral claims, blaming, and accusations of bias and double standards).

\section{Conclusion:}

Social media platforms are shaping political discourse in ways that are counterproductive to democratic debate. Debate or discussion across differences is incredibly rare in these spaces. While everyone has something to say, few are interested in listening. Political ideologies are reinforced through melodramatic political storytelling in which binary opposite meta-narratives are constructed around the exact same reported events. Marked by a highly affective and moralizing tone centred on the struggle between good and evil, melodramatic storytelling structures entrench political ideologies and polarization. Our analysis contributes myriad directions that encourage affective polarization and political communications scholarship to move beyond reductive, essentialized, and ahistorical conceptions of emotion, and to explore the ways in which platform structures reinscribe binary modes of thought and feeling that work against the possibility of genuine political conversation across difference. 


\section{References:}

Ahmed, S. (2014). Cultural politics of emotion. Edinburgh University Press.

Anker, E. (2005). Villains, Victims and Heroes: Melodrama, Media, and September 11. Journal of Communication 55, 22-37.

Berlant, L. (2008). The female complaint. Duke University Press.

Boler, M., \& Davis, E. (2018). The affective politics of the "post-truth" era: Feeling rules and networked subjectivity. Emotion, Space and Society, 27, 75-85.

Brooks, P. (1976). The Melodramatic Imagination: Balzac, Henry James, Melodrama, and the Mode of Excess. New Haven, CT: Yale University Press.

Bucholtz, M. (2019). The public life of white affects. Journal of Sociolinguistics, 23(5), 485-504.

Charmaz, K. (2006). Constructing grounded theory: A practical guide through qualitative analysis. Sage.

Duncan, P. K. (2017). The uses of hate: On hate as a political category. M/C Journal, 20(1).

Frye, N. (1957). Anatomy of criticism. Princeton, New Jersey: Princeton University Press

Ganesh, B. (2020) Weaponizing white thymos: flows of rage in the online audiences of the alt-right. Cultural Studies, (34)6, 892-924.

Hochschild, A. R. (2003). The commercialization of intimate life: Notes from home and work. Univ of California Press.

Hochschild, A. (2016, September). The American Right: Its Deep Story. Global Dialogue, 6(3). globaldialogue.isa-sociology.org/the-american-right-its-deep-story.

Kleres, J. (2011). Emotions and narrative analysis: A methodological approach. Journal for the theory of social behaviour, 41(2), 182-202.

LiteraryDevices Editors. (2021). Foil. Literary Devices. Retrieved from literarydevices.net/foil

Loseke, D. R. (Summer, 2009). Examining Emotion as Discourse: Emotion Codes and Presidential Speeches Justifying War. The Sociological Quarterly, 50(3), 497-524. 
Loseke, D. R. (2018). Narrative and the politics of meaning in a "post-fact" world. Social Problems, 65(1), 1-10.

Papacharissi, Z. (2016). Affective publics and structures of storytelling: Sentiment, events and mediality. Information, Communication \& Society, 19(3), 307-324.

Postman, N. (1986). Amusing ourselves to death: Public discourse in the age of show business. New York: Penguin Books.

Singer, B. (2001). Melodrama and Modernity: Early Sensational Cinema and its Contexts. New York: Columbia University Press.

Stark, L. (2020). Empires of feeling: Social Media and Emotive Politics. In Affective Politics of Digital Media (pp. 298-313). Routledge

Wagner-Pacifici, R. (1986). The Moro Morality Play: Terrorism as Social Drama. Chicago, IL: University of Chicago Press. 